\title{
Working
}

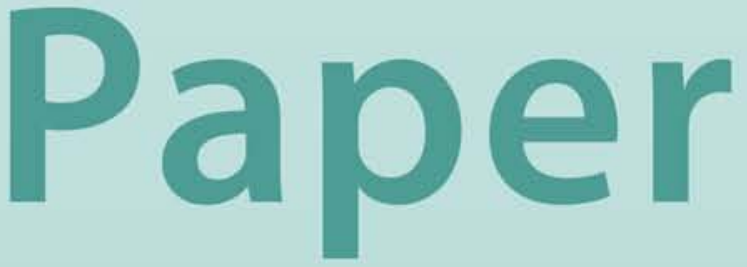




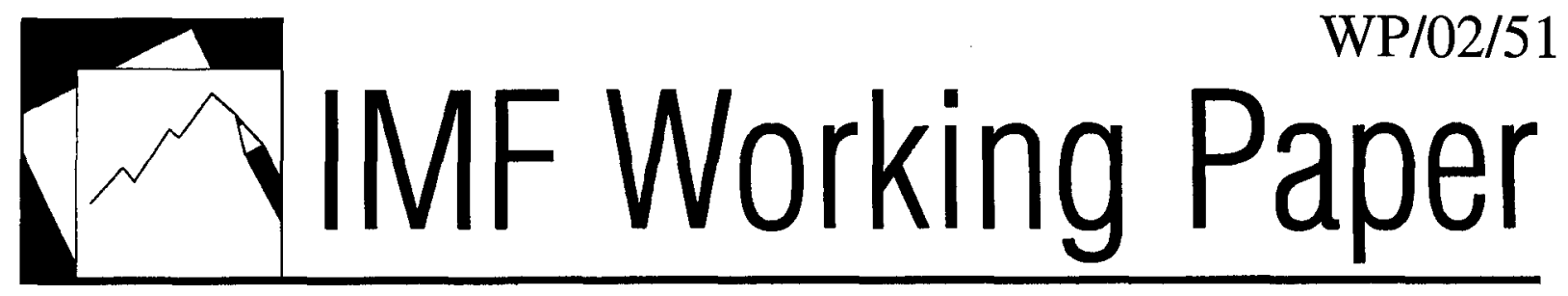

External Wealth, the Trade Balance, and the Real Exchange Rate

Philip R. Lane and

Gian Maria Milesi-Ferretti 


\title{
IMF Working Paper
}

\author{
European I Department
}

\section{External Wealth, the Trade Balance, and the Real Exchange Rate}

\author{
Prepared by Philip R. Lane and Gian Maria Milesi-Ferretti ${ }^{1}$ \\ Authorized for distribution by Thomas Krueger
}

March 2002

\begin{abstract}
The views expressed in this Working Paper are those of the author(s) and do not necessarily represent those of the IMF or IMF policy. Working Papers describe research in progress by the author(s) and are published to elicit comments and to further debate.
\end{abstract}

This paper examines the link between the net foreign asset position, the trade balance and the real exchange rate. In particular, it decomposes the impact of a country's net foreign asset position ("external wealth") on its long-run real exchange rate into two mechanisms: the relation between external wealth and the trade balance; and, holding other determinants fixed, a relation between the trade balance and the real exchange rate. It also provides additional evidence that the relative price of nontradables is an important channel linking the trade balance and the real exchange rate.

JEL Classification Numbers:F21, F31, F41

Keywords: Net foreign assets, trade balance, real exchange rate

Author’s E-Mail Address:plane@tcd.ie, gmilesiferretti@imf.org

${ }^{1}$ Philip R. Lane is Professor at Trinity College, Dublin. This paper was prepared for the 2001 EEA/NBER International Seminar on Macroeconomics held in Dublin, June 8-9. A slightly shorter version is forthcoming in the European Economic Review, June 2002. The authors thank their discussants Barry Eichengreen and Richard Portes, and two anonymous referees, for useful comments. They are also grateful to Patrick Honohan, Guy Meredith, Sam Ouliaris, Eswar Prasad, Andy Rose, Kees Koedijk, Maarten van Rooij, Neil Rankin, and seminar participants at ISOM, the European Central Bank, the Centre for Central Banking Studies, the International Monetary Fund, the Netherlands Central Bank, the Bank of Spain, Princeton, Columbia and the Federal Reserve Bank of New York. Mathias Hoffman provided efficient research assistance. Part of this work was carried out while Lane was a visiting scholar in the research departments of the IMF and the Federal Reserve Bank of New York. Lane's work on this paper is part of a research network on 'The Analysis of International Capital Markets: Understanding Europe's Role in the Global Economy', funded by the European Commission under the Research Training Network Programme (Contract No. HPRN-CT-1999-00067). Philip Lane also gratefully acknowledges the support of a TCD Berkeley Fellowship and the TCD Provost's Academic Development Fund. 


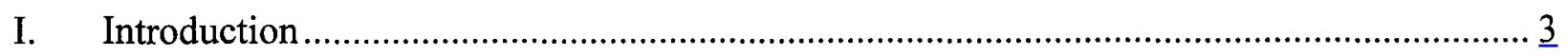

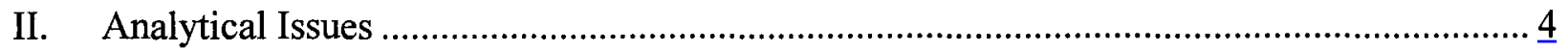

A. External Wealth and the Trade Balance............................................................. $\underline{5}$

B. The Trade Balance and the Real Exchange Rate ............................................... $\underline{6}$

III. External Wealth and the Trade Balance............................................................... $\underline{8}$

IV. The Real Exchange Rate, the Relative Price of Nontradables and the Trade Balance:

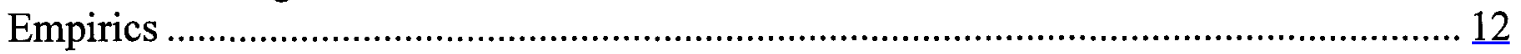

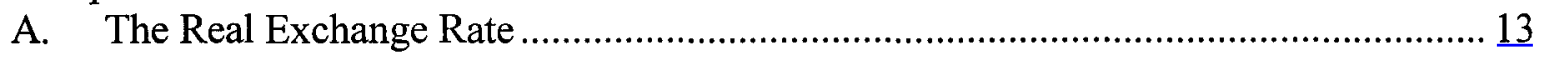

B. The Relative Price of Nontradables .......................................................... 15

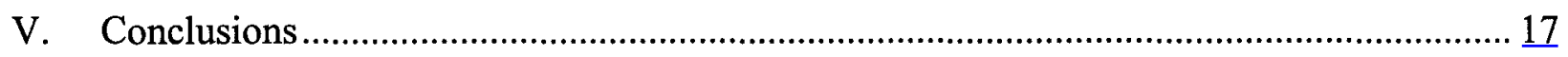

Tables

1. Trade Balance and Adjusted Returns........................................................................ 18

2. Trade Balance, Net Foreign Assets and Adjusted Returns: Cross-Sectional

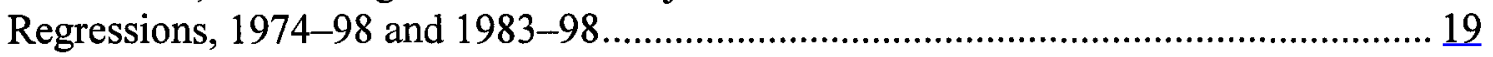

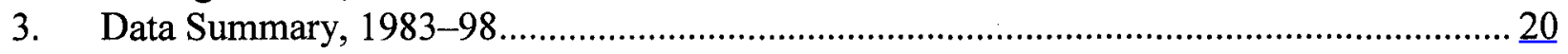

4. Stationarity and Cointegration Tests .................................................................... 21

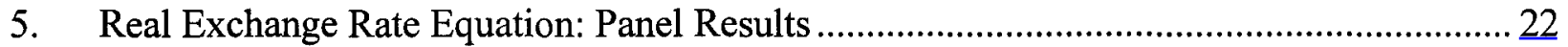

6. Relative Price of Nontradables.............................................................................. 23

7. Ratio of Home Relative Price of Nontradables to Foreign Relative Price of Nontradables

Figures

1. Trade Balance and Adjusted Returns ................................................................ 25

2. Net Foreign Assets in 1982 and Average Trade Balance, 1983-98 ............................... 26

3. The Trade Balance the Real Exchange Rate: Country Size ..........................................27

Appendices

I. Data Sources and Definitions..................................................................... 28

II. Construction of Adjusted Returns Term .......................................................... 30

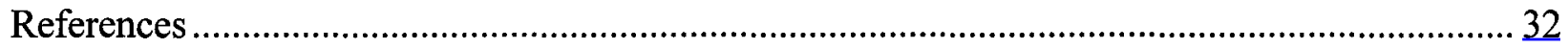




\section{INTRODUCTION}

The rapid growth in the net external liabilities of the United States and its implications for a possible reversal in the current strength of the dollar are a dominant theme of discussion in economic policy circles. This theme is certainly not new: the debate on the relation between international payments and real exchange rates has a long and distinguished intellectual history, and was at the forefront in the late 1920s, with the debate between Keynes and Ohlin on the impact of German war reparations, in the 1970s, with the debate on the implications of oil price shocks, in the early 1980s in the aftermath of the debt crisis, and in the mid- and late 1980s, with the debate on causes and consequences of the large swings in the value of the dollar. ${ }^{2}$

In this paper, we revisit the relation between international transactions, net external asset positions, and the real exchange rate, making use of a new data set on external assets and liabilities that we recently constructed (Lane and Milesi-Ferretti, 2001a). Our approach is empirical, and focuses on long-run relations between these variables. In simple terms, the standard argument linking net foreign assets, the trade balance and the real exchange rate runs as follows. A positive steady-state net external asset position enables a country to run persistent trade deficits. In turn, all else equal, the capability to sustain a negative net export balance in equilibrium is associated with an appreciated real exchange rate. Conversely, a debtor country that must run trade surpluses to service its external liabilities may require a more depreciated real exchange rate.

In previous empirical work, Faruqee (1995), Gagnon (1996), Broner, Loayza, and López (1997), Alberola, Cervero, López and Ubide (1999), and Lane and Milesi-Ferretti (2000) have provided estimates of a positive long-run relation between net foreign assets and the real exchange rate, using a variety of data, methods and specifications. ${ }^{3}$ In this paper, we instead decompose this relation into two parts: (i) the relation between the net foreign asset position and the trade balance; and (ii) the relation between the trade balance and the real exchange rate. We argue that explicitly allowing for this decomposition is important both theoretically and empirically, and provide econometric evidence to back this argument.

Indeed, the size of the trade surplus that a debtor country has to run to service its external liabilities will depend on the rate of return it has to pay on these liabilities, as well as on its output growth rate. For instance, going back to the U.S. example, a debtor country that grows quickly and manages to earn returns on its foreign assets that are higher than the payouts on its foreign liabilities requires a much smaller trade surplus to stabilize its net foreign asset position than a country with poor growth performance and unfavorable net investment income flows. By extension, the magnitude of any real exchange rate depreciation will be smaller in

${ }^{2}$ See also Krugman $(1987,1991)$ and Obstfeld and Rogoff (2001a).

${ }^{3}$ Lane and Milesi-Ferretti (2000) emphasize the relative price of nontradables as the primary endogenous component of the real exchange rate. In contrast, the other papers rule out any effect of external payments on the relative price of nontradables by including proxies for that relative price as regression controls. 
the former case. In the empirical analysis, we provide direct evidence on how the relation between the trade balance and net foreign assets depends on investment returns, output growth and exchange rate movements.

We also highlight that the link between trade balance and real exchange rate depends on other factors, such as relative output per capita, relative productivity levels, and the terms of trade, and we provide evidence on the economic and statistical significance of long-run comovements between these variables. The empirical analysis focuses on a sample of OECD economies for the period 1970-98. By selecting this group of countries for which higherquality data are available, we are able to refine our empirical analysis-for instance, by directly controlling for productivity variables in estimating the long-run relation between the trade balance and the relative price of nontradables. In addition to the trade balance, our empirical findings confirm the importance of relative productivity as a key determinant of the relative price of nontraded goods and the real exchange rate.

The structure of the rest of the paper is as follows. Section II discusses some analytical issues that are important in interpreting the subsequent empirical work. The relation between the net foreign asset position and trade balance is explored in Section III. Section IV estimates longrun equations for the real exchange rate and the relative price of nontradables as a function of the trade balance, plus some control variables. Some concluding remarks are offered in Section V.

\section{ANALYTICAL ISSUES}

The steady state of a standard intertemporal open-economy model typically involves the equilibrium equations ${ }^{4}$

$$
\begin{aligned}
& t b=-r^{*} b \\
& r e r=-\phi t b+\lambda X
\end{aligned}
$$

where $t b$ is the trade balance to GDP ratio, $r^{*}$ the rate of return on external assets and liabilities, $b$ is the stock of net foreign assets as a ratio to GDP, rer is the $(\log )$ CPI-based real exchange rate, and $X$ are other factors affecting the real exchange rate. ${ }^{5}$ Equation (1) just states that a country can run a steady-state trade deficit equal to the net investment income on its net foreign asset position. Equation (2) says that, for given values of other factors $X$, the real exchange rate will be more depreciated, the bigger the steady-state trade surplus.

Equations (1) and (2) can be solved to yield

$$
r e r=\phi r^{*} b+\lambda X \equiv \alpha b+\lambda X
$$

\footnotetext{
${ }^{4}$ For example, see Mussa (1984), Obstfeld and Rogoff (1996, Ch. 10) and Lane and Milesi-Ferretti (2000). This system assumes a zero-growth steady state. We introduce the implications of non-zero growth later in this section.

${ }^{5}$ An increase in rer corresponds to a real appreciation.
} 
That is, all else equal, the real exchange rate is increasing in the net foreign asset position of the country. This is the type of equation typically estimated in the empirical literature on the long-run relation between net foreign assets and real exchange rates.

However, this approach is potentially restrictive for two reasons. First, rates of return vary across countries, over time and between different categories of assets and liabilities. ${ }^{6}$ Second, in a non-zero growth environment, the "intrinsic dynamics" of the net foreign asset position depends on the output growth rate as well as rates of return. These qualifications suggest that we can obtain extra information on the mechanics of the transfer effect by separately considering the relations between net foreign assets and the trade balance and between the trade balance and the real exchange rate.

\section{A. External Wealth and the Trade Balance}

Accordingly, we rewrite the trade balance equation in a more general form. If we assume for simplicity that the rates of return on external assets and external liabilities are equal, the longrun condition for trade balance can be written as

$$
t b_{t} \equiv-\left[\frac{\left(1+r_{t}\right)-\left(1+g_{t}\right)\left(1+\dot{e}_{t}\right)}{\left(1+g_{t}\right)\left(1+\dot{e}_{t}\right)}\right] b_{t-1}+\varepsilon_{t} \equiv-\Psi_{t}+\varepsilon_{t}
$$

where $t b_{t}$ and $b_{t-1}$ are the ratios of the trade balance and net foreign assets to GDP respectively, $r_{t}$ is the real rate of return on foreign assets and liabilities in U.S. dollars, comprising yields and capital gains, $g_{t}$ is the real GDP growth rate of the economy, and $\dot{e}_{t}$ is the rate of real exchange rate appreciation vis-à-vis the U.S. dollar. The term multiplying $b_{t-1}$ can also be written as $\left(i_{t}-\gamma_{t}\right) /\left(1+\gamma_{t}\right)$, where $i_{t}$ is the nominal rate of return and $\gamma$ the nominal GDP growth rate, both in U.S. dollars. The disturbance term $\varepsilon_{t}$ captures temporary deviations from this long-run value, reflecting cyclical disturbances and shifts in the desired net foreign asset position. Appendix II clarifies how equation (4) is altered when the rates of return on gross assets and gross liabilities differ.

We label $\Psi_{t}$ the 'adjusted returns' variable: it determines the size of the trade imbalance - as a function of outstanding external wealth, investment returns, output growth and exchange rate movements - that is consistent with a unchanging ratio of net foreign assets to GDP. In the long run, we should observe an inverse relation between the net foreign asset position and the trade balance if the rate of return exceeds the growth rate $\left(i_{t}>\gamma_{t}\right)$.

\footnotetext{
${ }^{6}$ In a stochastic environment, expost returns will vary even if exante returns were equalized, depending on which "state of nature" is realized in a given period.
} 


\section{B. The Trade Balance and the Real Exchange Rate}

We measure the real exchange rate as the ratio of consumer prices in the home country relative to its trading partners, expressed in a common currency. The reduced-form specification for the real exchange rate equation is as follows

$$
r e r_{t}=q\left(t b_{t}, y d_{t}, t t_{t}\right)+\mu_{t} \quad q_{t b}<0, q_{y d}>0, q_{t t}>0
$$

where an increase in the $(\log )$ real exchange rate index rer ${ }_{t}$ corresponds to a real appreciation, $y d_{t}$ is the log of relative GDP per capita, $t t_{t}$ is log of the terms of trade and $\mu_{t}$ is a disturbance term.

We will also empirically examine the (log) relative price of nontradables

$$
p_{N t}-p_{T t}=p\left(t b_{i t}, y c_{i t}, \operatorname{rprod}_{i t}, t t_{i t}\right)+v_{i t} \quad p_{t b}<0, p_{y c}>0, p_{r p r o d}>0, p_{t t}>0
$$

where $y c_{t}$ is log GDP per capita, rprod is the log of the ratio of sectoral labor productivity in the tradable sector versus the nontradable sector and $v_{t}$ is a disturbance term.

A variety of open-economy models can generate specifications such as equations (5) and (6). Especially for a small open economy, the primary endogenous component of the real exchange rate is the relative price of nontraded goods. ${ }^{7}$ A weak real exchange rate in a country that runs a persistent trade surplus may be attributed to several factors. ${ }^{8}$ First, the negative wealth effect of maintaining absorption below production lowers demand for nontradables. ${ }^{9}$ Second, this negative wealth effect also potentially raises labor supply, reducing costs in the nontraded sector. Third, a decline in the relative price of nontradables may also be useful in providing incentives for mobile factors to shift from the domestic to the

\footnotetext{
${ }^{7}$ As emphasized by Obstfeld and Rogoff (2001b), there is a strong parallel between twosector models with traded and nontraded goods and models in which all goods are tradable but transport costs are significant and there is limited substitutability between home and foreign goods. The reader may prefer this alternative framework, according to taste.

${ }^{8}$ Lane and Milesi-Ferretti (2000) describe a simple dynamic general equilibrium model that generates a negative steady-state effect of the trade balance on the relative price of nontradables. The model also identifies the terms of trade and relative output per capita as additional determinants of the long-run real exchange rate. We return to these variables later in this section.

${ }^{9}$ The wealth effect of a given net foreign asset position is captured by the additional "permanent income" it generates. In turn, it is the level of these investment returns (inclusive of net capital gains) that determines the long-run trade imbalance that a country can maintain.
} 
export sector. These forces all point to an inverse relation between the trade balance and the relative price of nontradables. ${ }^{10}$

It should be noted that there is also a transitional relation between these variables in portfolio balance models: a country that must run surpluses to converge to its desired long-run net foreign asset position will experience real depreciation along the transition path (see Branson and Henderson, 1985; and Alberola and others 1999). ${ }^{11}$ More generally, various business cycle shocks will generate short-term comovements between the trade balance and the real exchange rate. However, our focus in this paper is on the long-run relation between these variables.

For countries with market power in international markets, trade imbalances may also affect the structure of international relative prices. For instance, a trade deficit may be associated with a strengthening of the external terms of trade, since an increase in the price of exports relative to imports could accompany a contraction in net exports. Although there is not necessarily a mechanical connection between the terms of trade and the CPI-based real exchange rate, a terms of trade improvement will lead to real appreciation if there is a home bias in the tradables consumption basket and/or the associated positive wealth effect raises demand for, and reduces the supply of, nontradables. Due to the latter mechanism, terms of trade movements are a potential source of shifts in the real exchange rate. Although the terms of trade may in part be endogenously determined for larger countries, exogenous terms of trade movements are likely to predominate for smaller countries. Accordingly, we directly control for the terms of trade in our empirical work, so that any relation between the trade balance and the real exchange rate in our specification will not be operating via the terms of trade channel.

In addition to the terms of trade, we also control for the impact of relative output per capita. It is well understood that an improvement in productivity in the traded sector relative to the nontraded sector can generate an increase in the relative price of nontradables by driving up economy-wide real wage levels: this is the "Balassa-Samuelson" effect. We will directly control for productivity for the subsample of countries for which sectoral productivity data are available. For the broader panel of countries, we employ relative output per capita as a control variable. In part, this may proxy for the relative productivity effect since output per capita and relative traded-sector productivity are likely to be positively correlated.

${ }^{10}$ It is well understood that there exist a range of conditions under which the relative price of nontradables depends only on relative sectoral productivity (see Obstfeld and Rogoff, 1996, chapter 4). Some departure from these conditions is required for the trade balance effect to be operative.

${ }^{11}$ Alberola and others only estimate the long-run relation between the net foreign asset position and the real exchange rate and do not empirically address the transitional features of the portfolio balance model. 
However, relative output per capita may also exert additional influences on the real exchange rate. By the same mechanisms described above for the wealth effect of a positive net foreign asset position (via the capability to run persistent trade deficits), a rise in output per capita may be associated with an increase in demand for nontradables and a contraction in labor supply. ${ }^{12}$ In addition, if tastes are nonhomothetic and the income elasticity of demand for nontradables is greater than one, this may further apply upward pressure on the relative price of nontradables (Bergstrand, 1991).

It is also worth noting that controlling for relative output per capita serves a useful additional purpose in seeking to capture the long-run relation between the trade balance and the real exchange rate, since relative output per capita controls for any effects of historical current account imbalances on the level of output via past effects on the path for domestic investment.

\section{External Wealth AND The Trade BALANCE}

In this section, we examine the relation between the balance on goods and services, the net external position, its composition, and the "adjusted returns" term $\Psi_{t}$. Our sample spans the period 1970-98 and includes 20 OECD countries. ${ }^{13}$ The data on the trade balance come from the IMF's Balance of Payments Statistics and refer to the balance of goods, services and transfers. ${ }^{14}$ We use two sources of data for net foreign assets: the estimates we constructed in Lane and Milesi-Ferretti (2001a) ("adjusted cumulative current account"), which are available for the period 1970-98, and the International Investment Position data (IIP) reported in the IMF's Balance of Payments Statistics, which are generally available for a shorter period. Appendix A provides more details on data sources and definitions for all variables.

The ratio of nominal investment returns to GDP is calculated as the sum of net investment income and net capital gains on outstanding external assets and liabilities measured in

\footnotetext{
${ }^{12}$ Note that, using relative output per capita should be similar to using relative income per capita, since we are holding fixed the trade balance (which we argue in the long run is negatively related to net investment income flows, the primary difference between income per capita and output per capita).

${ }^{13}$ The sample here excludes Belgium, because the balance of payments data refer to Belgium and Luxembourg but the net foreign asset data to Belgium only, and Ireland, a country for which measurement of the trade balance and net investment income in the 1990s is strongly affected by transfer pricing issues. Data availability for the balance of goods and services starts, for some countries, in the mid-1970s.

${ }^{14}$ We employ here the trade balance inclusive of current transfers since a trade surplus and an inward transfer are equivalent ways to finance a given level of debt service payments. As a practical matter, the inclusion of transfers matters mostly for Greece. In the real exchange rate section, we just use the balance on goods and services since it is the difference between domestic production and absorption that should matter for the real exchange rate.
} 
U.S. dollars, divided by GDP in U.S. dollars $\left(i_{t} B_{t-1} / Y_{t}\right){ }^{15}$ To calculate real returns, we subtract the impact of U.S. inflation on the outstanding stocks of net foreign assets. The "adjusted returns" term is calculated as the difference between the ratio of nominal returns to GDP $i_{t} B_{t-1} / Y_{t}$ and the impact of GDP growth on the ratio of outstanding net foreign assets to GDP $\gamma_{t} B_{t-1} / Y_{t}$.

Equation (4) in the paper postulates the existence of a long-run relation between the trade balance and the 'adjusted returns' term $\Psi_{t}$ along the time series dimension. Table 1 shows that that both variables are nonstationary but that the residual from equation (4) is stationary. ${ }^{16}$ That is, a cointegration test with $(1,-1)$ coefficients imposed (in line with the theory) is easily accepted. Put differently, we find that the two components of changes in the ratio of net foreign assets to GDP (the trade balance and "adjusted returns") are individually nonstationary but the change in the net foreign asset position is stationary. ${ }^{17}$

We turn to the cross-sectional dimension in Table 2. Our dependent variable is the trade balance averaged over the period 1974-98 (columns (1), (3), (5)) and 1983-98 (columns (2), (4) and (6)). To check for the robustness of our results, we use IIP data as our measure of net foreign assets for the period 1983-98 whenever possible. ${ }^{18}$ Our explanatory variables are the stock of net foreign assets at the beginning of the sample period, the average "adjusted returns" term and its components. From columns (1) and (2), it is clear that there is no crosssectional relation between the initial net foreign asset position and the subsequent average

${ }^{15}$ When we use the "adjusted cumulative current account" measure of net foreign assets we can only estimate capital gains and losses on FDI and portfolio equity assets and liabilities, but not on debt instruments. The Appendix describes how such capital gains and losses are estimated. When we use the IIP measure of net foreign assets we can calculate capital gains and losses on all components of net foreign assets (as the difference between the change in the stock and the underlying flow).

${ }^{16}$ All panel unit root and cointegration tests in the paper were performed using the NPT 1.2 package for GAUSS that has been developed by Chiang and Kao (2001).

${ }^{17}$ Our goal here is to highlight the long-run relation between the trade balance and adjusted returns. In turn, adjusted returns depend on the long-run net foreign asset position (plus rates of return and growth rates). In Lane and Milesi-Ferretti (2001b), we have explored the determinants of the net foreign asset position (including relative output levels, fiscal positions and demographic variables), plus their contribution to the dynamic short-run adjustment of the trade balance towards its long-run value.

${ }^{18}$ We use the IIP data for Austria, Canada, Finland, Germany, Italy, Japan, the Netherlands, Spain, Sweden, Switzerland, the United Kingdom, the United States. For the remaining countries, IIP data is available only for a shorter period or not available at all. Results are analogous if we use our own measure of net foreign assets for all countries for the same period. 
trade balance. However, the relation between the average trade balance and the adjusted returns variable is close to one-to-one: countries with positive adjusted returns run trade deficits, while countries with negative adjusted returns run trade surpluses.

To our knowledge, the only other study that has looked at whether flow measures respond to the initial external stock position is Chinn and Prasad (2000) who conduct a cross-country study of the determinants of medium-term current account balances. Their findings for industrial countries suggest that the initial stock position is positively correlated with subsequent current account balances along the cross-sectional dimension, while there is no relation within countries between initial net foreign assets and subsequent current account balances. Since the current account is the sum of the trade balance and net factor income, our cross-sectional finding of no relation between the initial net foreign asset position and the trade balance can be reconciled with a positive relation with the current account, since net investment income is obviously positively related to net external wealth. In the time-series analysis in (Table 1), we found the first difference of the net foreign asset position to be stationary and cointegration to exist between the trade balance and adjusted returns. Once again, this result is consistent with the lack of a time-series relation between initial net foreign assets and the current account reported by Chinn and Prasad.

The cross-section relation between the average adjusted returns and the average trade balance is also illustrated graphically in Figure 1. Over the 1974-98 period, countries that enjoyed positive adjusted returns (such as the United States, the United Kingdom, and Greece) ran average trade deficits; conversely, those countries that on net were paying out adjusted returns (such as the Netherlands, Canada, Denmark, and Finland) ran average trade surpluses. Figure 2 shows instead the relation (or lack thereof) between the average trade balance over the period 1983-98 and the stock of net foreign assets at the end of 1982: differences in rates of return and growth rates means that the cross-section relation between net foreign assets and the trade balance is weaker than the relation between adjusted returns and the trade balance. When we break down the adjusted returns element into its underlying components in columns (4) and (5) of Table 2, we find that both the real return and the growth component are highly significant and have a coefficient that is statistically not different from minus one.

The next logical step in the analysis is an investigation of differences in rates of return between different countries, different periods and different foreign asset classes. However, as Appendix II makes clear, attempting to infer the "net" rates of return $i$ or $r$ directly (rather than multiplied by the ratio of lagged net foreign assets to GDP) is an exercise fraught with problems, which can be especially severe for countries that have net foreign asset positions not far from zero. The reason is that net investment income is given by the difference between returns on external assets and on external liabilities, and such returns will not in general be equal. ${ }^{19}$ As a result, it is possible for a country to have nonzero net investment income or returns even when its net foreign asset position is zero. Simply dividing net investment

${ }^{19}$ The United States had net external liabilities but positive net investment income during most of the 1990s. 
income by the lagged net foreign assets when the denominator approaches zero gives clearly biased results.

The problem can be addressed if we can estimate with confidence the gross stocks of external assets and liabilities, and therefore the rates of return on external assets and external liabilities separately. With the net foreign asset data we constructed we have estimates of the gross positions only for portfolio equity and FDI, but for the debt component we can only provide estimates of the net position. However, the IIP data provide measures of all gross assets and liabilities, albeit for a smaller set of countries and a shorter period of time. In Table 3 we use this data for the period 1983-98 to cast further light on our regression results. We report the initial net foreign asset position, its period average, the trade balance, adjusted returns, real returns (all as ratios to GDP), median real rates of return on external assets and external liabilities for those countries that have IIP data available for a sufficiently long period of time (at least ten years), and finally the average rate of growth and real appreciation. We present these findings with a note of caution: measurement error issues are pervasive and different methodologies in calculating the value of external assets and liabilities in IIP data complicate cross-country comparisons.

One of the most striking stylized facts emerging from the table is the high median real rate of return on external assets and liabilities (nominal dollar returns minus U.S. inflation) for most countries (mean and median are above 6 percent). The main factor behind this result is the impact of capital gains on FDI and equity holdings-indeed, the mean and median values of real yields (not reported) are around 4 percent. We discuss further the impact on returns of equity capital gains and losses below. ${ }^{20}$

Debtor countries such as Canada, Finland, New Zealand, Spain, and Sweden have negative average adjusted returns (column (4)) and negative average net foreign assets (column (1)), suggesting a positive $i_{t}-\gamma_{t}$. Conversely, the adjusted returns term is positive for debtor countries such as Greece, Portugal and the United States and negative for creditor countries such as Germany and the Netherlands, suggesting that $i_{t}-\gamma_{t}$ is negative. However, if we look at columns (6)-(9) it is clear that the rates of return on external assets and liabilities are higher than the combined growth/real appreciation effect, most clearly in Japan, the Netherlands and the United States.

What is at work here is a rate of return differential between external assets and liabilities (positive for the United States, negative for Japan and the Netherlands) which makes the average ratio of real returns to GDP (and the adjusted returns term) positive for a debtor

\footnotetext{
${ }^{20}$ Unfortunately, with the exception of a few countries such as the United States and the United Kingdom, we do not have a breakdown on investment income flows by asset category, and cannot, therefore, calculate rates of return on different asset classes.
} 
country like the U.S. and negative for creditor countries such as Germany, Japan, and the Netherlands. $^{21}$

But what factors account for the high measured rates of return on U.S. assets and liabilities? Capital gains on FDI and equity holdings are the main factor. Unlike most other countries, the United States calculates direct investment assets and liabilities (and not only portfolio equity holdings) at market value, rather than book value. This implies that the rapid increase in stock market values worldwide during the 1990s had a particularly strong impact on rates of return. Indeed, if we net out capital gains and losses on FDI and equity instruments from returns, the return on U.S. assets drops to 5.3 percent and the return on U.S. liabilities to 3.4 percent. If we repeat the same exercise for the other countries in our sample, rates of return are also reduced, albeit less drastically than in the United States: for example, the returns on U.K. assets and liabilities drop to 4.5 percent and 4 percent, respectively.

As shown in column (5), only two countries have positive real returns on average during the sample period. In an accounting sense, this is explained by the fact that only four countries had positive net foreign assets throughout the period (Germany, Japan, the Netherlands, and Switzerland) and all of them had higher rates of return on liabilities than on assets. More generally, measurement error problems are more severe for returns on assets than on liabilities, because of underreporting of investment income earnings on assets.

\section{The Real Exchange Rate, the Relative Price of Nontradables and the TRADE BALANCE: EMPIRICS}

Having established a link between the net foreign asset position and the trade balance, the objective of the second part of our empirical exercise is to capture the long-run relation between the trade balance and the real exchange rate.

We begin by examining the time series properties of the data in Table 4 . We construct a multivariate CPI-based real exchange rate and the same trade weights are employed to construct relative output per capita as the difference between domestic GDP per capita and the weighted average of the GDP per capita of each country's main trading partners (see Appendix I for more details on the definitions and sources of variables). The panel unit root tests all indicate that a null of stationarity can be rejected for all the variables we consider in this section. However, for both the real exchange rate and the relative price of nontradables specifications (equations (5) and (6) above), cointegration tests indicate that a stationary longrun relation exists among the variables. ${ }^{22}$

\footnotetext{
${ }^{21}$ See Appendix II for the expression corresponding to the ratio of real returns and adjusted returns to GDP when there are rates of return differentials between assets and liabilities.

${ }^{22}$ Further details on the unit root and cointegration tests are available from the authors upon request. As is well known from the PPP literature, tests of the null of nonstationarity offer more mixed results but the null of stationarity is more relevant for our purposes.
} 
Having established that a cointegration framework is appropriate, estimation is by dynamic ordinary least squares (DOLS $(-1,1)){ }^{23}$ Accordingly, the general form of the panel regression for the real exchange rate is

$$
\begin{aligned}
r e r_{i t}=\alpha_{i} & +\phi_{t}+\beta_{1}{ }^{*} t b_{i t}+\beta_{2} * \log \left(y d_{i t}\right)+\beta_{3} * \log \left(t t_{i t}\right)+\sum_{k=-1}^{k=1} \rho_{1 k} \Delta t b_{i t-k} \\
& +\sum_{k=-1}^{k=1} \rho_{2 k} \Delta \log \left(y d_{i t-k}\right)+\sum_{k=-1}^{k=1} \rho_{3 k} \Delta \log \left(t t_{i t-k}\right)+\mu_{i t}
\end{aligned}
$$

where $\alpha_{i}$ and $\phi_{t}$ are country and time fixed effects. ${ }^{24}$ Including the leads and lags of the first differences of the regressors improves efficiency in estimating the long-run coefficients $\beta_{1}, \beta_{2}, \beta_{3}$. The $\beta$ coefficients capture the relation between the long-run values of the regressors and the long-run real exchange rate.

\section{A. The Real Exchange Rate}

The results for the real exchange rate equation are shown in Table 5. In columns (1)-(2), the full panel is employed. The sample is then split between the non-G3 and G3 countries in columns (3)-(4) and (5)-(6), respectively. It is natural to expect a difference in the sensitivity of the real exchange rate to various fundamentals between large and small countries: for instance, the relative size of the nontraded sector typically varies directly with the size of the country. In all cases, country fixed effects are employed: these are necessary since the real exchange rate data are index measures and therefore not comparable across countries. We report results both with and without time fixed effects.

The trade balance enters significantly in all specifications in Table $5 .{ }^{25}$ Taking the specification that includes time dummies, the trade balance coefficient for the full panel is -0.72 . However, the split between the non-G3 and G3 subsamples reveals a large difference in magnitude. For the non-G3 countries, a 3 percentage points increase in the trade surplus as a ratio to GDP is associated with only a 1 percent real depreciation. For the G3 countries, by contrast, the same improvement in the trade balance is associated with a 19.3 percent real depreciation.

A similar story applies for the role played by relative output per capita: in all specifications, its relation with the real exchange rate is significantly positive but the point coefficient is ten times larger for the G3 than for the non-G3 countries-a 10 percent increase in relative output

${ }^{23}$ Stock and Watson (1993) originally developed the DOLS estimator. See Mark and Sul (1999) and Kao and Chiang (1999) on its performance as an estimator of long-run relations in panel data. In turns out that an ARDL specification generates very similar results for our sample.

${ }^{24}$ A similar specification is employed for the relative price of nontradables.

${ }^{25}$ Note that our variable is the nominal trade balance as a ratio to GDP. Since we control for the terms of trade in the regression, we capture the effect of the 'real' trade balance. 
per capita is associated with less than a 2 percent real appreciation for the non-G3 countries but a 19 percent real appreciation for the $\mathrm{G} 3$ countries.

Finally, the terms of trade is significantly positive for the full panel and the non-G3 countries but is insignificant for the G3 countries. Country-by-country estimation reveals that the latter result is attributable to the Japanese data: the country results for the United States and Germany indicate a unitary coefficient for the terms of trade in the real exchange rate equation. For the non-G3 countries, the terms of trade coefficient is 0.52 : a 10 percent improvement in the terms of trade is associated with a 5.2 percent real appreciation. By holding fixed the terms of trade, we emphasize that the observed relation between the trade balance and the real exchange rate must be operating through some other channel, such as the relative price of nontradables.

Overall, the results in Table 5 provide broad support for an inverse long-run relation between the trade balance and the real exchange rate, holding fixed relative output per capita and the terms of trade. As a cointegration equation, these estimates are consistent even if there is correlation between the regressors and the error term. ${ }^{26}$ We can go further and interpret the equation as "quasi-structural" in the sense of Davidson (1998), if the long-run real exchange rate does not play a role in determining the long-run trade balance. Although there is considerable short-term feedback between the real exchange rate and the trade balance, the long-term trade balance should depend on those factors that drive the long-run net foreign asset position. ${ }^{27}$ The literature on the determinants of net foreign assets points to factors such as demography, fiscal positions and relative incomes: we know of no theory that generates a direct dependence of the long-run net foreign asset position on the long-run value of the real exchange rate (see also Lane and Milesi-Ferretti, 2001). Rather the real exchange rate adjusts in the long run as an equilibrium response to the level of the trade balance that is associated with the desired long-run net foreign asset position.

We note that our estimated long-run equation for the real exchange rate could form the basis for calculating 'fundamental equilibrium' real exchange rates. In particular, we would argue that the trade balance is a key variable that should be included in such an exercise. However, this step would also require an assessment of the appropriate equilibrium long-run values for the explanatory variables in the equation, which is beyond the scope of this paper (see Driver and Westaway, 2001 for a recent review).

In results available from the authors, we also ran country-by-country regressions. The point estimate on the trade balance is negative in 19 out of 21 cases: all else equal, real exchange rates tend to be more depreciated, the larger is the trade balance surplus. ${ }^{28}$ As is illustrated in

\footnotetext{
${ }^{26}$ See Hayashi (2000) for a review of the properties of cointegration estimators.

${ }^{27}$ Of course, the determinants of the long-run growth rate and rates of return also matter.

${ }^{28}$ With respect to the other real exchange rate determinants, there is a positive relation between relative output and the real exchange rate for 14 countries ( 9 significant): countries that experience a relative improvement in output per capita tend to experience real
} 
Figure 3, a negative relation between country size and the magnitude of the trade balance coefficient is clearly evident in the data (the correlation is -0.46$){ }^{29}$ This is to be expected: in standard open-economy models, the deterioration in the real exchange rate that is associated with a given improvement in the trade balance is directly related to the relative size of the nontraded sector in the economy.

\section{B. The Relative Price of Nontradables}

We turn now to examining whether we can directly observe a relation between the trade balance and the relative price of nontradables, even when we directly control for the impact of differential relative sectoral productivity growth. We build proxies for sectoral productivity and sectoral prices from the OECD's Intersectoral Database (ISDB): this provides sufficient data for thirteen of the countries in our sample. ${ }^{30}$ The "manufacturing" sector is taken to represent the tradable sector; the nontraded sector is proxied by an aggregate of "construction," "community, social and personal services," and "producers of government services." "We follow Canzoneri, Cumby, and Diba (1999) in taking labor productivity (value added divided by the number of employees) as the appropriate productivity variable. Sectoral prices are measured by the value added deflators.

The relative price of nontradables is the dependent variable in Table 6 . We consider a slightly altered set of regressors: in addition to the productivity variable, our focus on the relative price of nontradables domestically means that we employ here GDP per capita $\left(y c_{i t}\right)$ rather than relative GDP per capita $\left(y d_{i t}\right)$. As in Table 5, columns (1)-(2) employ the full panel; columns (3)-(4) include only the non-G3 countries; and column (5)-(6) show the results for the G3 sub-panel.

Consistent with De Gregorio, Giovannini, and Wolf (1994), Asea and Mendoza (1994) and Canzoneri and others (1999), relative sectoral productivity enters very strongly in determining the relative price of nontradables. However, it turns out that the trade balance is also a

appreciation. Finally, the terms of trade enters with a positive sign in 18 out of 21 cases (11 significant).

${ }^{29}$ Country size is measured by total GDP in 1990, in constant U.S. dollars.

${ }^{30}$ These are the United States, Japan, Germany, France, Italy, the United Kingdom, Canada, Denmark, Finland, Norway, Australia, Belgium, and Sweden. The Netherlands is also in the database but the data coverage is very poor.

31 This selection maximizes data availability, since other services sectors (such as financial services) are available only for a small number of countries over a narrow time interval. Moreover, as is pointed out by McDonald and Ricci (2001), the "wholesale and retail trade" sector that is often incorporated into the nontraded bundle in fact more closely resembles a tradable sector in its characteristics. 
significant variable in determining the relative price of nontradables. The estimated point coefficients in columns (4) and (6) suggest that a one percentage point improvement in the trade balance is associated with a decline in the relative price of nontradables of 0.75 percent and 1.21 percent for the non-G3 and G3 countries, respectively.

Although there is a difference between the non-G3 and G3 countries in these point estimates, it is much smaller in magnitude than in the real exchange rate regressions in Table 6. These findings can be reconciled by the fact that the relative price of nontradables is a more important component in the consumer price level in larger, more closed economies: the same change in the relative price of nontradables translates into a much bigger change in the CPIbased real exchange rate for a large country than for a small country. ${ }^{32}$

With respect to the other regressors, the output per capita variable should capture demand factors or wealth effects on the supply of labor, since productivity is now directly included in the specification. In fact, the evidence on this variable is mixed: for the G3 countries, there is a significantly positive relation between output per capita and the relative price of nontradables but this is not the case for the non-G3 countries. Finally, there is weak evidence that the terms of trade positively affects the relative price of nontradables (more so for the non-G3 countries).

The findings in Table 6 refer to the determinants of the domestic relative price of nontradables. What matters for the evolution of the real exchange rate is the ratio of the relative price of nontradables at home to the relative price of nontradables overseas. Accordingly, we report results for this "double" relative price in Table 7. By extension, we now use the difference in the log of relative sectoral productivity between the home country and its trading partners (drprod) and relative GDP per capita in logs $(y d)$ as the relevant regressors, in addition to the trade balance and the terms of trade.

The results in Table 7 are broadly similar to those in Table 6 . Cross-country variation in relative sectoral productivity are very important in explaining differentials in the relative price of nontradables. As before, the trade balance is important in explaining the relative price of nontradables relative to trading partners, although it loses significance for the G3 countries if time dummies are excluded from the specification. However, for the specification that includes time dummies (columns (4) and (6)), the point estimate for the G3 countries is almost triple that for the non-G3 countries. Although substantial, this differential is much smaller than in the real exchange rate equations in Table 5 , in line with the different weights of nontradables in the consumption baskets of large versus small countries.

In contrast to Table 6, (relative) output per capita is significant in all specifications in Table 7. The point estimates suggest that this variable exerts a bigger impact for the G3 countries than the non-G3 countries: the magnitude of the coefficient is twice as large for the specification

\footnotetext{
${ }^{32}$ Following Obstfeld and Rogoff (2001a, 2001b), nontradables should be broadly interpreted for this purpose to encompass all goods whose price is ultimately determined by domestic conditions.
} 
that includes time fixed effects (columns (4) and (6)). Finally, the terms of trade are significant only for the non-G3 countries in Table 7. We may expect a more important role for the terms of trade in smaller (more open) economies, since the wealth effect of a terms of trade improvement positively depends on the volume of export/import activity.

In summary, the empirical results in this section establish a link between the trade balance and the real exchange rate: in the long run, larger trade surpluses are associated with more depreciated real exchange rates. Furthermore, the magnitude of the trade balance coefficient is positively related to country size. Taken together, the results of Sections 3 and 4 illustrate a key mechanism by which the net foreign asset position is an important fundamental driver of the real exchange rate: conditional on the patterns of investment returns and output growth, countries with positive net external wealth are able to run persistent trade deficits; in turn, a pattern of trade deficits is associated with long-run real appreciation of the real exchange rate.

\section{Conclusions}

This paper has explored the links between the net foreign asset position, the trade balance and the real exchange rate. We have shown that the relation between external wealth and the trade balance within and across countries is related to the rates of return on external assets and liabilities and the rate of output growth. Controlling for other determinants, we have established a negative long-run association between the trade balance and the real exchange rate. Moreover, we find that the magnitude of the trade balance coefficient is increasing in country size and we provide direct evidence that the relative price of nontradables co-moves with the trade balance, even controlling for relative sectoral productivity.

Our work has focused on long-run relations, and has not explored the short-run dynamics of the relation between the trade balance and the real exchange rate. Interesting issues here include possible nonlinearities in the convergence of the exchange rate to its long-run value. Another challenge is the identification of alternative structural shocks that may generate different short-run co-movements between the trade balance and the real exchange rate. Finally, the paper has highlighted the important role played by differences in rates of return on external assets and liabilities in shaping the dynamics of net foreign assets. Understanding the sources of these differences in rates of return is an important topic on the research agenda. 
Table 1. Trade Balance and Adjusted Returns

A. Stationarity tests

\begin{tabular}{ccc}
\hline & Z-statistic & P-value \\
\hline Trade Balance & 8.38 & 0.00 \\
Adjusted Returns & 3.05 & 0.00 \\
& & \\
\hline & B. Cointegration test & \\
Trade Balance, & Z-statistic & P-value \\
Adjusted Returns & 0.53 & 0.30 \\
\hline
\end{tabular}

Note: Hadri (2000) test for null of stationarity applied. Cointegration test is test of null of stationarity of the residual from equation (4). Balanced panel applied in all cases. Z-stat has asymptotically normal distribution; p-values calculated by Monte Carlo method. 
Table 2. Trade Balance, Net Foreign Assets and Adjusted Returns:

Cross-Sectional Regressions, 1974-98 and 1983-98

\begin{tabular}{lllllll}
\hline & $(1)$ & $(2)$ & $(3)$ & $(4)$ & $(5)$ & $(6)$ \\
& $\begin{array}{l}\text { Trade } \\
\text { Balance }\end{array}$ & $\begin{array}{l}\text { Trade } \\
\text { Balance }\end{array}$ & $\begin{array}{l}\text { Trade } \\
\text { Balance }\end{array}$ & $\begin{array}{l}\text { Trade } \\
\text { Balance }\end{array}$ & $\begin{array}{l}\text { Trade } \\
\text { Balance }\end{array}$ & $\begin{array}{l}\text { Trade } \\
\text { Balance }\end{array}$ \\
& $1974-98$ & $1983-98$ & $1974-98$ & $1983-98$ & $1974-98$ & $1983-98$ \\
\hline $\begin{array}{l}\text { Initial net foreign assets } \\
\text { (ratio of GDP) }\end{array}$ & 0.008 & 0.002 & 0.017 & 0.006 & & \\
& $(0.40)$ & $(0.15)$ & $(1.16)$ & $(0.52)$ & & \\
Adjusted Returns/GDP & & & -0.940 & -0.677 & & \\
& & & $(4.05)^{* * *}$ & $(3.16)^{* * *}$ & & -0.678 \\
Real Returns/GDP & & & & & -0.939 & $(3.22)^{* * *}$ \\
& & & & & -1.790 & -0.920 \\
Growth term/GDP & & & & & $(3.95)^{* * *}$ & $(2.60)^{* *}$ \\
& & & & & 20 & 20 \\
$\begin{array}{l}\text { Observations } \\
\text { Adjusted R }\end{array}$ & 20 & 20 & 20 & 20 & & 0.30 \\
$\begin{array}{l}\text { F-test adjusted returns=-1 } \\
\text { (p-val in par.) }\end{array}$ & & -0.05 & 0.44 & 0.32 & 0.53 & \\
$\begin{array}{l}\text { Joint f-test compon. adj. } \\
\text { returns = -1 } \\
\text { (p-val in par.) }\end{array}$ & & & 0.07 & 2.28 & & \\
\hline
\end{tabular}

Note: The trade balance, adjusted returns, returns and growth effects are averages over the periods, 1974-98 (columns (1), (3), (5)) and 1983-98 (columns (2), (4), (6)). Net foreign assets are the outstanding stocks at the beginning of each period. For the 1974-98 regressions, we use the CUMCA measure of net foreign assets. For the period 1983-98 we use International investment Position data for the following countries: Austria, Canada, Finland, Germany, Italy, Japan, Netherlands, Spain, Sweden, Switzerland, the United Kingdom, the United States. t-statistics in parentheses. ${ }^{* *},{ }^{* *},{ }^{*}$ denote significance at the 1 percent, 5 percent and 10 percent confidence level, respectively. 
Table 3. Data Summary, 1983-98

\begin{tabular}{|c|c|c|c|c|c|c|c|c|c|}
\hline Country & $\begin{array}{c}\text { (1) } \\
\text { Avg NFA } \\
\text { (ratio of GDP) }\end{array}$ & $\begin{array}{c}\text { (2) } \\
\text { NFA in } 1983 \\
\text { (ratio of GDP) }\end{array}$ & $\begin{array}{c}(3) \\
\text { Trade Balance } \\
\text { (ratio of GDP) }\end{array}$ & $\begin{array}{c}\text { (4) } \\
\text { Adj. Returns } \\
\text { (ratio of GDP) }\end{array}$ & $\begin{array}{c}\text { (5) } \\
\text { Real Returns } \\
\text { (ratio of GDP) }\end{array}$ & $\begin{array}{c}(6) \\
\text { Median real } \\
\text { rate of return } \\
\text { Assets }\end{array}$ & $\begin{array}{c}(7) \\
\text { Median Real } \\
\text { Rate of Return } \\
\text { Liabilities }\end{array}$ & $\begin{array}{c}\text { (8) } \\
\text { Avg. } \\
\text { Change in } \\
\text { RER }\end{array}$ & $\begin{array}{c}\text { (9) } \\
\text { Avg. Real } \\
\text { Growth Rate }\end{array}$ \\
\hline United States & -5.0 & 3.6 & -2.4 & 1.0 & 0.9 & 11.3 & 8.1 & 0.0 & 2.2 \\
\hline United Kingdom & 6.0 & 12.7 & -1.7 & -0.5 & -0.1 & 6.6 & 7.1 & 1.3 & 2.2 \\
\hline Austria & -11.5 & -10.1 & -0.1 & -0.5 & -0.9 & 6.5 & 8.3 & 1.9 & 2.0 \\
\hline Denmark & -22.6 & -34.0 & 3.0 & -1.4 & -2.6 & & & 2.0 & 2.2 \\
\hline France & -0.1 & 1.0 & 0.6 & -0.6 & -0.6 & 8.5 & 8.9 & 1.2 & 1.5 \\
\hline Germany & 10.9 & 3.8 & 0.8 & -1.0 & -0.2 & 2.9 & 4.3 & 1.7 & 1.0 \\
\hline Italy & -7.0 & -5.2 & 1.2 & -0.5 & -0.7 & 8.3 & 9.6 & 2.0 & 1.8 \\
\hline Netherlands & 26.1 & 23.7 & 3.5 & -2.9 & -2.3 & 5.9 & 7.3 & 0.7 & 2.2 \\
\hline Norway & -3.2 & -22.1 & 3.7 & -1.0 & -1.2 & & & -0.6 & 2.7 \\
\hline Sweden & -30.0 & -19.1 & 2.2 & -2.8 & -3.1 & 11.7 & 11.0 & 0.6 & 1.3 \\
\hline Switzerland & 97.2 & 70.2 & 1.3 & -0.1 & 3.7 & 6.9 & 8.7 & 1.7 & 0.8 \\
\hline Canada & -38.9 & -36.8 & 1.3 & -1.8 & -2.2 & 3.6 & 4.2 & -1.4 & 1.5 \\
\hline Japan & 13.2 & 2.4 & 1.8 & -1.9 & -1.7 & 7.0 & 9.6 & 2.3 & 2.3 \\
\hline Finland & -34.6 & -17.8 & 2.3 & -5.4 & -5.7 & 0.4 & 7.2 & 0.6 & 1.9 \\
\hline Greece & -42.2 & -32.2 & -1.2 & 0.5 & -1.0 & & & 1.2 & 1.4 \\
\hline Iceland & -34.4 & -31.6 & 1.2 & -1.4 & -2.3 & 6.0 & 3.3 & 0.7 & 1.4 \\
\hline Portugal & -30.4 & -51.4 & -0.1 & 1.0 & -0.6 & & & 3.1 & 2.9 \\
\hline Spain & -14.9 & -14.1 & 0.1 & -0.7 & -0.9 & 6.1 & 6.9 & 1.5 & 2.5 \\
\hline Australia & -45.3 & -26.3 & -1.3 & -1.0 & -1.6 & 6.1 & 3.5 & -1.8 & 2.3 \\
\hline New Zealand & -64.0 & -42.4 & 0.9 & -3.1 & -4.5 & & & 0.2 & 0.7 \\
\hline
\end{tabular}

Note: the NFA data is the International Investment Position (IIP) data for the following countries: Austria, Canada, Finland, Germany, Italy, Japan, the Netherlands, Spain, Sweden, Switzerland, the United Kingdom, the United States. For the remaining countries, we use our own estimate of NFA. The median real rates of return can only be calculated for those countries for which IIP data are available. Among those, we excluded those countries for which IIP data are available for less than ten years. 
Table 4. Stationarity and Cointegration Tests

\begin{tabular}{ccc}
\hline & A. Stationarity tests & \\
\hline$r e r$ & Z-statistic & P-value \\
$t b$ & 10.75 & 0.00 \\
$y d$ & 10.29 & 0.00 \\
$t t$ & 18.78 & 0.00 \\
$p_{N}-p_{T}$ & 10.79 & 0.00 \\
$r p r o d$ & 12.56 & 0.00 \\
$y c$ & 11.01 & 0.00 \\
& 9.11 & 0.00 \\
$(r e r, t b, y d, t t)$ & & \\
$\left(p_{N}-p_{T}, t b, r p r o d, y c, t t\right)$ & B. Cointegration tests & P-value \\
\hline
\end{tabular}

Note: Hadri (2000) unit root test for null of stationarity. Pedroni (1999) Group-t test for null of no cointegration among a multivariate vector. Balanced panels employed. 
Table 5. Real Exchange Rate Equation: Panel Results

\begin{tabular}{|c|c|c|c|c|c|c|}
\hline & (1) & (2) & (3) & (4) & (5) & (6) \\
\hline & Full Sample & Full Sample & Non-G3 & Non-G3 & G3 & G3 \\
\hline$t b$ & $\begin{array}{l}-0.51 \\
(2.83)^{* * *}\end{array}$ & $\begin{array}{l}-0.72 \\
(3.33)^{* * *}\end{array}$ & $\begin{array}{l}-0.38 \\
(2.28)^{* *}\end{array}$ & $\begin{array}{l}-0.33 \\
(1.64)^{*}\end{array}$ & $\begin{array}{l}-5.64 \\
(5.15)^{* * *}\end{array}$ & $\begin{array}{l}-6.44 \\
(3.79)^{* * *}\end{array}$ \\
\hline$y d$ & $\begin{array}{l}0.4 \\
(3.8)^{* * *}\end{array}$ & $\begin{array}{l}0.39 \\
(5.66)^{* * *}\end{array}$ & $\begin{array}{l}0.18 \\
(2.02)^{* *}\end{array}$ & $\begin{array}{l}0.19 \\
(2.83)^{* *}\end{array}$ & $\begin{array}{l}1.61 \\
(5.82)^{* * *}\end{array}$ & $\begin{array}{l}1.89 \\
(5.32)^{* * *}\end{array}$ \\
\hline$t t$ & $\begin{array}{l}0.44 \\
(7.5)^{* * *}\end{array}$ & $\begin{array}{l}0.55 \\
(11.68)^{* * *}\end{array}$ & $\begin{array}{l}0.48 \\
(10.46)^{* * *}\end{array}$ & $\begin{array}{l}0.52 \\
(10.95)^{* * *}\end{array}$ & $\begin{array}{l}0.19 \\
(1.33)\end{array}$ & $\begin{array}{l}0.05 \\
(0.25)\end{array}$ \\
\hline Adjusted $\mathbf{R}^{2}$ & 0.51 & 0.55 & 0.54 & 0.57 & 0.65 & 0.62 \\
\hline Number of observ. & 519 & 519 & 442 & 442 & 77 & 77 \\
\hline Number of countries & 21 & 21 & 18 & 18 & 3 & 3 \\
\hline Time dummies? & no & yes & no & yes & no & yes \\
\hline
\end{tabular}

Note: The sample comprises all countries in columns (1)-(2); Germany, Japan, and the United States (G-3) are excluded from the regressions in columns (3)-(4); the sample comprises Germany, Japan, and the United States only in columns (5)-(6). Estimation is by DOLS; t-statistics in parentheses. ${ }^{* * *}, * *, *$ denote significance at the 1 percent, 5 percent and 10 percent confidence level, respectively. 
Table 6. Relative Price of Nontradables

\begin{tabular}{|c|c|c|c|c|c|c|}
\hline & (1) & $(2)$ & (3) & (4) & (5) & (6) \\
\hline & Full Sample & Full Sample & Non-G3 & Non-G3 & G3 & G3 \\
\hline \multirow[t]{2}{*}{$t b$} & -1.17 & -1.15 & -0.59 & -0.75 & -0.98 & -1.21 \\
\hline & $(6.2)^{* * *}$ & $(6.49)^{* * *}$ & $(3.3)^{* * *}$ & $(3.72)^{* * *}$ & $(1.97)^{*}$ & $(2.19)^{* *}$ \\
\hline \multirow[t]{2}{*}{ rprod } & 0.66 & 0.71 & 0.76 & 0.76 & 0.68 & 0.63 \\
\hline & $(16.7)^{* * *}$ & $(17.3)^{* * *}$ & $(18.4)^{* * *}$ & $(17.8)^{* * *}$ & $(8.35)^{* * *}$ & $(5.18)^{* * *}$ \\
\hline \multirow[t]{2}{*}{$y c$} & 0.03 & 0.56 & -0.26 & 0.13 & 0.35 & 0.89 \\
\hline & $(.51)$ & $(4.24)^{* * *}$ & $(4.72)^{* * *}$ & $(.96)$ & $(3.54)^{* * *}$ & $(4.48)^{* * *}$ \\
\hline \multirow[t]{2}{*}{$t t$} & 0.19 & 0.1 & 0.12 & 0.1 & 0.16 & 0.004 \\
\hline & $(4.33)^{* * *}$ & $(2.01)^{* *}$ & $(2.57)^{* * *}$ & $(1.71)^{*}$ & $(3.1)^{* * *}$ & $(.4)$ \\
\hline Adjusted $\mathrm{R}^{2}$ & 0.86 & 0.89 & 0.86 & 0.88 & 0.97 & 0.97 \\
\hline Number of observ. & 280 & 280 & 212 & 212 & 68 & 68 \\
\hline Number of countries & 13 & 13 & 10 & 10 & 3 & 3 \\
\hline Time dummies? & No & Yes & No & Yes & No & Yes \\
\hline
\end{tabular}

Note: The sample comprises all countries in columns (1)-(2); Germany, Japan, and the United States (G3) are excluded from the regressions in columns (3)-(4); the sample comprises Germany, Japan, and United States only in columns (5)-(6). DOLS estimation; tstatistics in parentheses. Nontradables: weighted sum of "construction," "community, social and personal services," and "government services"; tradables: "manufacturing". rprod: log of relative labor productivity in traded versus nontraded sector. $* * *, * *, *$ denote significance at the 1 percent, 5 percent and 10 percent confidence level, respectively. 
Table 7. Ratio of Home Relative Price of Nontradables to Foreign Relative Price of Nontradables

(1)

(2)

(3)

(4)

(5)

(6)

\begin{tabular}{|c|c|c|c|c|c|c|}
\hline & Full Sample & Full Sample & Non-G3 & Non-G3 & G3 & G3 \\
\hline$t b$ & $\begin{array}{l}-0.77 \\
(3.83)^{* * *}\end{array}$ & $\begin{array}{l}-0.97 \\
(3.99)^{* * *}\end{array}$ & $\begin{array}{l}-0.76 \\
(3.47)^{* * *}\end{array}$ & $\begin{array}{l}-0.88 \\
(3.03)^{* * *}\end{array}$ & $\begin{array}{l}-0.89 \\
(1.28)\end{array}$ & $\begin{array}{l}-2.26 \\
(3.94)^{* * *}\end{array}$ \\
\hline drprod & $\begin{array}{l}0.92 \\
(15.82)^{* * *}\end{array}$ & $\begin{array}{l}0.93 \\
(15.2)^{* * *}\end{array}$ & $\begin{array}{l}0.91 \\
(12.29)^{* * *}\end{array}$ & $\begin{array}{l}0.93 \\
(12.5)^{* * *}\end{array}$ & $\begin{array}{l}0.85 \\
(8.2)^{* * *}\end{array}$ & $\begin{array}{l}0.56 \\
(4.15)^{* * *}\end{array}$ \\
\hline$y d$ & $\begin{array}{l}0.57 \\
(5.27)^{* * *}\end{array}$ & $\begin{array}{l}0.55 \\
(4.2)^{* * *}\end{array}$ & $\begin{array}{l}0.44 \\
(2.93)^{* * *}\end{array}$ & $\begin{array}{l}0.43 \\
(2.47)^{* *}\end{array}$ & $\begin{array}{l}0.68 \\
(4.19)^{* * *}\end{array}$ & $\begin{array}{l}0.95 \\
(4.68)^{* * *}\end{array}$ \\
\hline$t t$ & $\begin{array}{l}0.05 \\
(1.09)\end{array}$ & $\begin{array}{l}0.09 \\
(1.39)\end{array}$ & $\begin{array}{l}0.13 \\
(2.2)^{* *}\end{array}$ & $\begin{array}{l}0.14 \\
(1.86)^{*}\end{array}$ & $\begin{array}{l}-0.02 \\
(.4)\end{array}$ & $\begin{array}{l}-0.11 \\
(1.0)\end{array}$ \\
\hline Adjusted $R^{2}$ & 0.85 & 0.84 & 0.84 & 0.84 & 0.87 & 0.91 \\
\hline Number of observ. & 248 & 248 & 186 & 186 & 62 & 62 \\
\hline Number of countries & 13 & 13 & 10 & 10 & 3 & 3 \\
\hline Time dummies? & No & Yes & No & Yes & No & Yes \\
\hline
\end{tabular}

Note: The sample comprises all countries in columns (1)-(2); Germany, Japan, and the United States (G3) are excluded from the regressions in columns (3)-(4); the sample comprises Germany, Japan, and the United States only in columns (5)-(6). DOLS estimation; t-statistics in parentheses. Nontradables: weighted sum of "construction," "community, social, and personal services," and "government services"; tradables: "manufacturing." drprod: $\log$ of relative labor productivity in traded versus nontraded sector at home minus log of relative labor productivity in trading partners. $* * *, * *, *$ denote significance at the 1 percent, 5 percent and 10 percent confidence level, respectively. 
Figure 1. Trade Balance and Adjusted Returns

(Averages, 1974-98)

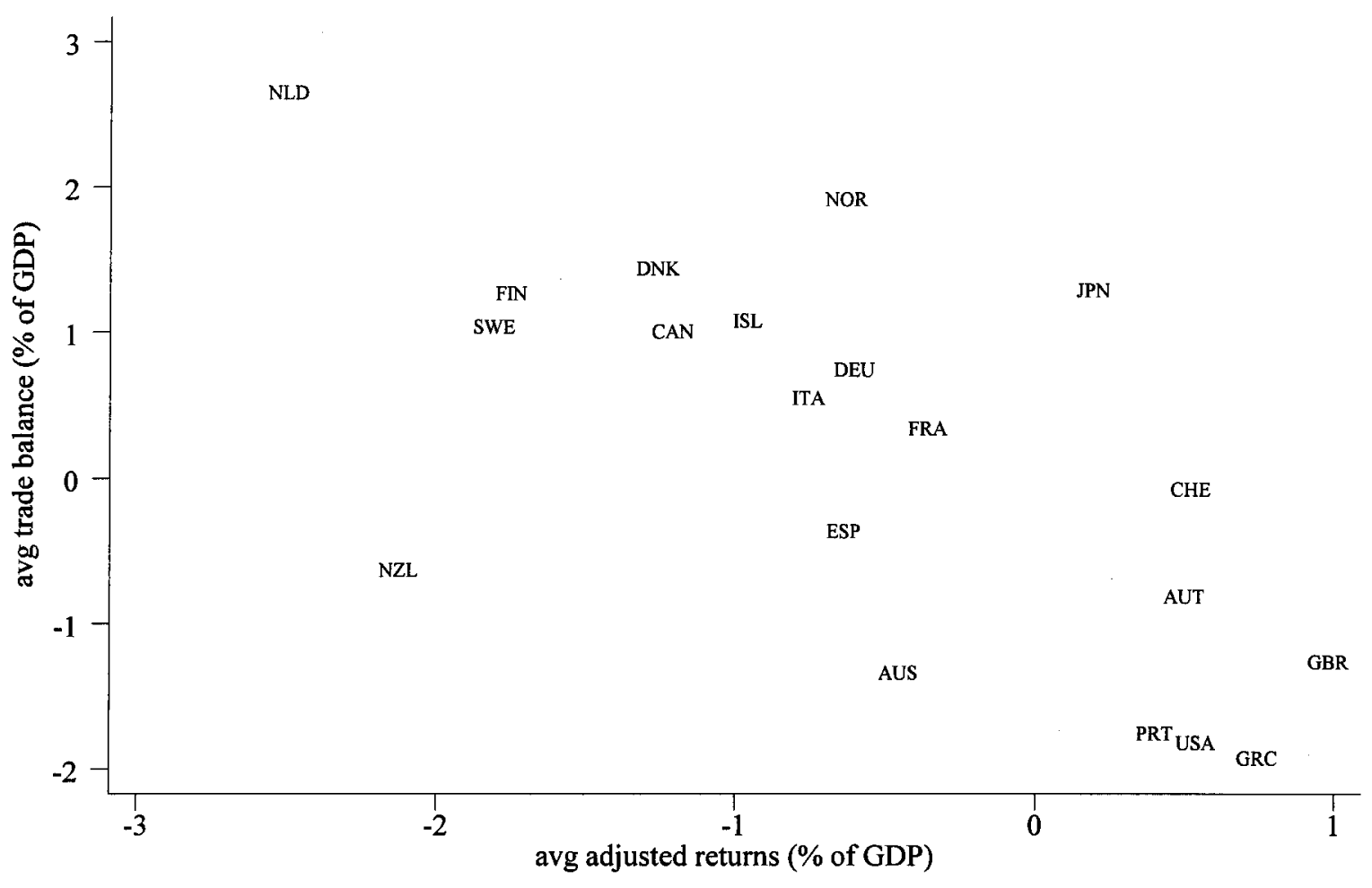

Note: The trade balance is defined as the balance on goods, services and transfers. See Appendix I for the definition of adjusted returns. Abbreviations are as follows:

AUS=Australia, AUT=Austria, $\mathrm{CAN}=\mathrm{Canada}, \mathrm{CHE}=$ Switzerland, $\mathrm{DEU}=$ Germany, $\mathrm{DNK}=$ Denmark, $\mathrm{ESP}=$ Spain, $\mathrm{FIN}=$ Finland, FRA $=$ France, $\mathrm{GBR}=$ United Kingdom, $\mathrm{GRC}=$ Greece, ISL=Iceland, ITA=Italy, JPN=Japan, NLD $=$ Netherlands, NOR=Norway, $\mathrm{NZL}=$ New Zealand, PRT=Portugal, $\mathrm{SWE}=$ Sweden, USA=United States. 
Figure 2. Net Foreign Assets in 1982 and Average Trade Balance, 1983-98

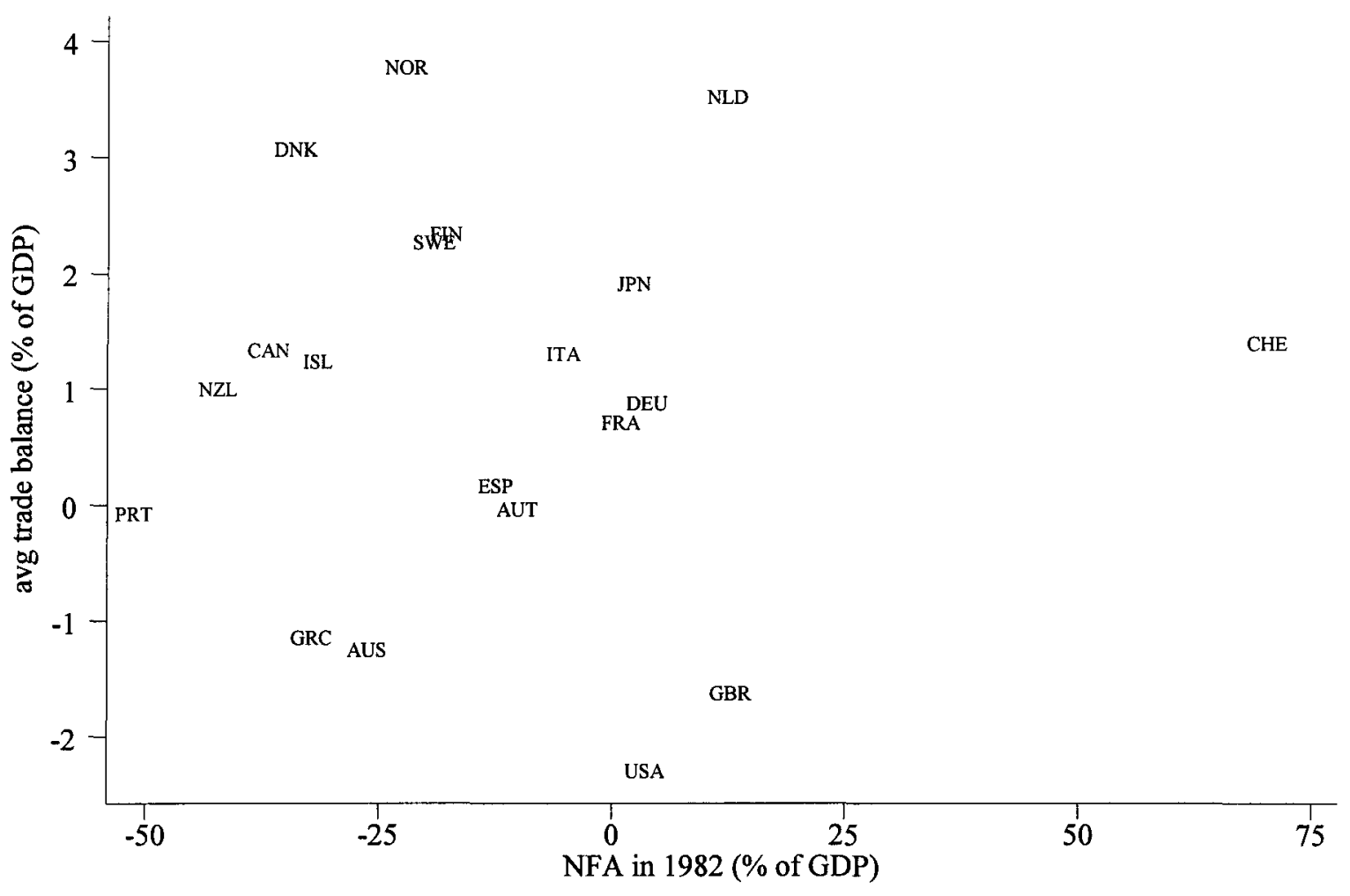

Note: The trade balance is defined as the balance on goods, services and transfers. NFA is measured as IIP (when available) or $b_{t}$ (when IIP is not available). For Switzerland, IIP for 1982 was calculated as IIP in 1984 minus the cumulated current account in 1982-1983. See Appendix I for definitions of IIP and $b_{t}$. For abbreviations see Note to Figure 1. 
Figure 3. The Trade Balance and the Real Exchange Rate: Country Size*

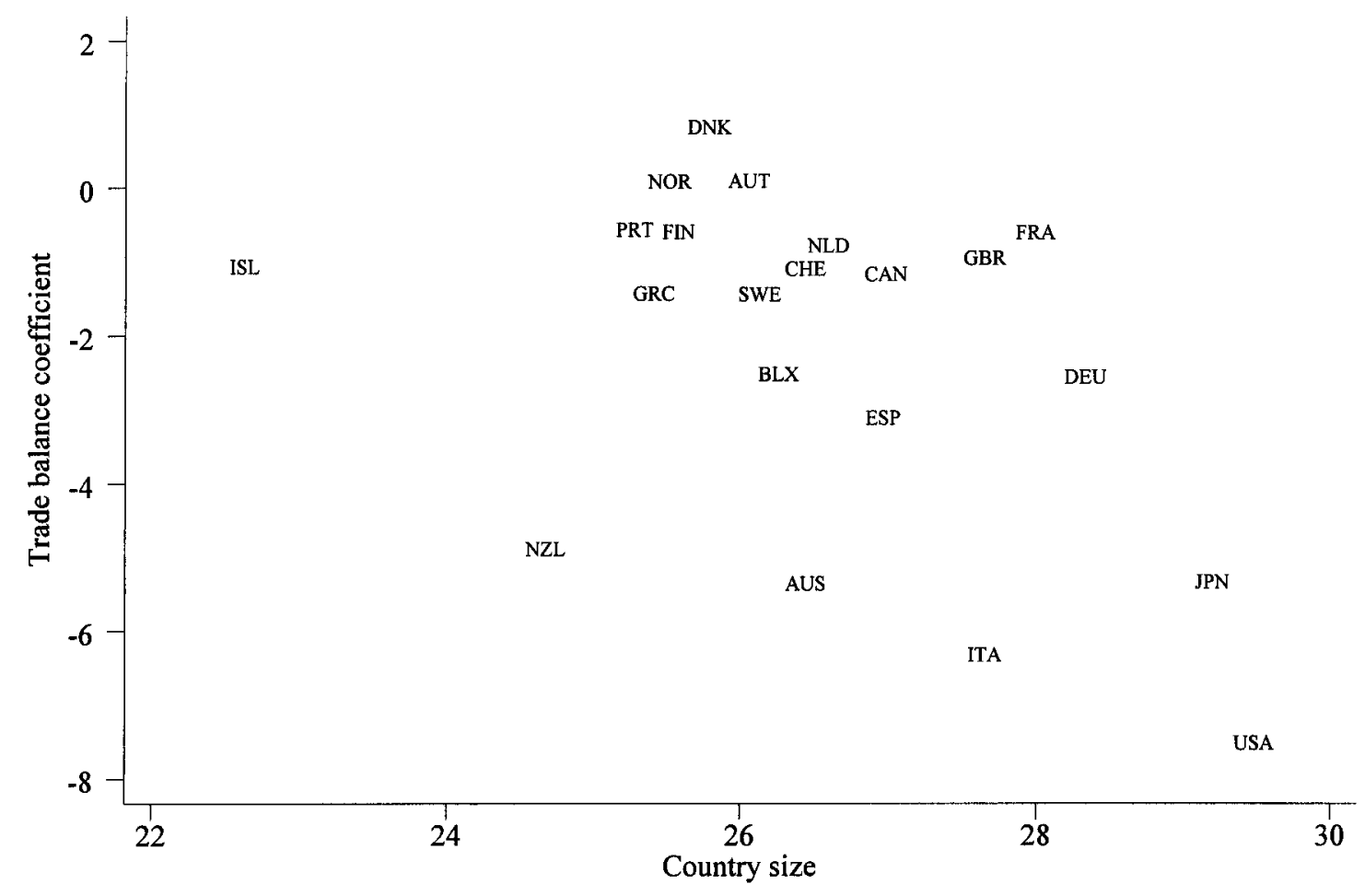

* Country size is the log of GDP in 1990, measured in constant U.S. dollars. The trade balance coefficient is the coefficient on the trade balance in country-by-country regressions of the real exchange rate on the trade balance, terms of trade and relative GDP per capita. 


\section{DATA SourCes AND DEFINITIONS}

$\boldsymbol{b}_{\boldsymbol{t}}$ : Net foreign assets, calculated as cumulative current account adjusted for capital account transfers and for valuation changes in portfolio equity assets and liabilities, FDI assets and liabilities, and foreign exchange reserves, as ratio of GDP. For further details on the valuation adjustments, see "Net Capital Gains" below and Lane and Milesi-Ferretti (2001a). Source: Lane and Milesi-Ferretti (2001a).

IIP: International Investment Position net of gold holdings. Source: IMF, Balance of Payments Statistics.

$\boldsymbol{t} \boldsymbol{b}$ : Balance on goods, services and transfers (ratio to GDP). Source: IMF's Balance of Payments Statistics, supplemented by OECD sources.

Net Investment Income: Investment income credits - investment income debits. Source: IMF, Balance of Payments Statistics.

Net Capital Gains: For the NFA measure, capital gains are differences between the estimated change in the stock of external assets (liabilities) and the underlying flow. For FDI assets, valuation changes are the estimated effects on outstanding FDI assets of changes in relative capital goods' prices between the countries of destination of FDI and the United States (the unit of measurement). The countries of destination of FDI are assumed to be the trading partners used in the calculation of the real effective exchange rate, and the relative price of capital goods across countries is assumed to follow relative consumer prices. For FDI liabilities, valuation changes are given by the impact on outstanding liabilities of changes in relative capital goods' prices between the home country and the United States, proxied by changes in the bilateral CPI-based real exchange rate. For portfolio equity investment assets, valuation changes reflect year-on-year changes in the U.S. dollar value of a representative "world" portfolio (the Morgan Stanley Capital Index). For portfolio equity investment liabilities valuation changes reflect year-on-year changes in the U.S. dollar value of the domestic stock market index. For foreign exchange reserves, we directly measure the difference between changes in the stock and the underlying flow (primarily due to crosscountry fluctuations). Capital gains calculated on IIP are differences between the actual change in the stock and the underlying flow. Source: Lane and Milesi-Ferretti (2001a) and IMF, Balance of Payments Statistics.

rret (real returns): Net investment income/GDP + net capital gains/GDP $-\pi_{t}^{\S} \frac{B_{t-1}}{Y_{t}}$ where $\pi_{t}^{\S}$ is the rate of inflation in the U.S. (measured with the U.S. GDP deflator).

Source: Authors' calculations. 
$\Psi$ (adjusted returns): Net investment income/GDP + net capital gains/GDP $-\frac{\gamma_{t}}{1+\gamma_{t}} b_{t-1}$, where $\gamma_{t}$ is the nominal GDP growth rate in U.S. dollars and $b_{\mathrm{t}-1}$ is the ratio of net foreign assets to GDP at the end of period t-1. Source: Authors' calculations.

rer: log of real effective exchange rate (CPI-based). Trade weights based on trade patterns in 1990, calculated using the IMF's Information Notice System (described in Desruelle and Zanello (1997)). Source: Authors' calculations based on CPI and exchange rate data from the International Monetary Fund.

$y d: \log$ of GDP per capita relative to trading partners. Partner countries' weights are the same as those used in the construction of RERCPI. Source: Authors' calculations based on the World Bank's World Development Indicators (WDI) database.

$\boldsymbol{t t}$ : $\log$ of ratio of export prices (or export unit values) to import prices (or import unit values), both expressed in U.S. dollars. Sources: OECD, Analytical Database; and IMF, International Financial Statistics.

$\boldsymbol{p}_{N}-\boldsymbol{p}_{T}: \log$ of price of nontraded goods relative to traded goods. The nontraded goods sector included construction, "community, social and personal services," and "producers of government services." The traded goods' sector is the manufacturing sector. Source: Authors' calculations based on OECD's International Sectoral Database (2000).

rprod: $\log$ of labor productivity in the traded goods' sector relative to the nontraded goods' sector. Source: Authors' calculations based on the OECD's International Sectoral Database (2000).

$y c$ : $\log$ of GDP per capita. Source: The World Bank's World Development Indicators (WDI) database.

drprod: rprod in the home country relative to a weighted average of rprod in trading partners. Source: Authors' calculations based on the OECD's International Sectoral Database (2000). 


\section{CONSTRUCTION OF ADJUSTED RETURNS TERM}

Changes in the net foreign asset position are due to current account imbalances and to capital gains and losses. Assume initially that external assets and liabilities earn the same rate of return. In this case, the dynamics of net foreign assets can be written as follows

$$
B_{t}-B_{t-1}=T B_{t}+T R_{t}+\left(i_{t}^{*}+k g_{t}\right) B_{t-1}
$$

where $T B$ is the balance on goods, services and transfers, $i_{t}^{*} B_{t-1}$ is investment income and $k_{t} B_{t-1}$ is the capital gain/loss on outstanding net external assets. Dividing both terms by GDP measured in U.S. dollars and re-arranging terms, we obtain

$$
\Delta b_{t}=t b_{t}+\frac{i_{t}^{*}+k g_{t}-\gamma_{t}}{1+\gamma_{t}} b_{t-1}
$$

Let $i_{t}=i_{t}^{*}+k g_{t}$, define $r_{t} \equiv \frac{1+i_{t}}{1+\pi_{t}^{\$}}-1=\frac{i_{t}-\pi_{t}^{\$}}{1+\pi_{t}^{\$}}$, and re-write $1+\gamma_{t}=\left(1+g_{t}\right)\left(1+\dot{e}_{t}\right)\left(1+\pi_{t}^{\$}\right)$ where $g_{t}$ is the economy's real growth rate, $\dot{e}_{t}$ the rate of real appreciation vis-à-vis the U.S. dollar and $\pi_{t}^{\$}$ is the U.S. inflation rate, where are the last two variables are measured in terms of GDP deflators. We can then re-write equation (B2) as follows

$$
t b_{t}=-\frac{\left(1+r_{t}\right)-\left(1+g_{t}\right)\left(1+\dot{e}_{t}\right)}{\left(1+g_{t}\right)\left(1+\dot{e}_{t}\right)} b_{t-1}+\Delta b_{t}
$$

which is equation (2) in the text. For the empirical analysis, we use both real returns, calculated as $\frac{i_{t}-\pi_{t}^{\$}}{1+\gamma_{t}} b_{t-1}$, and the "adjusted returns" term, given by $\Psi_{t}=\frac{i_{t}-\gamma_{t}}{1+\gamma_{t}} b_{t-1}$.

Assume now that the rate of return on gross external assets and liabilities can differ. Let $g f a_{t}$, $g f l_{t}$ be the stocks of gross foreign assets and gross foreign liabilities (as ratios of GDP), respectively, and define $i_{t}^{A}, i_{t}^{L}\left(r_{t}^{A}, r_{t}^{L}\right)$ as the nominal (real) U.S. dollar rate of return on gross foreign assets and liabilities, respectively. In this case our computed ratios of net real returns and adjusted returns to GDP are equal to

$$
\begin{aligned}
& \text { rret }_{t}=\frac{r_{t}^{A}}{\left(1+g_{t}\right)\left(1+\dot{e}_{t}\right)} b_{t-1}+\frac{\left(r_{t}^{A}-r_{t}^{L}\right)}{\left(1+g_{t}\right)\left(1+\dot{e}_{t}\right)} g f l_{t-1} \\
& \Psi_{t}=\frac{\left(1+r_{t}^{A}\right)-\left(1+g_{t}\right)\left(1+\dot{e}_{t}\right)}{\left(1+g_{t}\right)\left(1+\dot{e}_{t}\right)} b_{t-1}+\frac{\left(r_{t}^{A}-r_{t}^{L}\right)}{\left(1+g_{t}\right)\left(1+\dot{e}_{t}\right)} g f l_{t-1}
\end{aligned}
$$


Clearly in the presence of a non-zero $r_{t}^{A}-r_{t}^{L}$, attempting to measure $r$ as $\left[\operatorname{rret}_{t}\left(1+g_{t}\right)\left(1+\dot{e}_{t}\right)\right] / b_{t-1}$ gives biased results. The size of this bias grows, the closer is the net foreign asset position to balance and the larger the underlying gross stock positions. 


\section{REFERENCES}

Alberola, Enrique, Susana G. Cervero, Humberto Lopez, and Angel Ubide, 1999, "Global Equilibrium Exchange Rates: Euro, Dollar, Ins, Outs, and Other Major Currencies in a Panel Cointegration Framework," IMF Working Paper 99/175 (Washington: International Monetary Fund).

Asea, Patrick K., and Enrique G. Mendoza, 1994, "Balassa-Samuelson: A General Equilibrium Approach," Review of International Economics, Vol. 23, pp. 244-67.

Bergstrand, Jeffrey H., 1991, "Structural Determinants of Real Exchange Rates and National Price Levels: Some Empirical Evidence," American Economic Review, Vol. 81, pp. 325-34.

Branson, William, and Dale Henderson, 1985, "The Specification and Influence of Asset Markets," in Handbook of International Economics, ed. by R.W. Jones and P.B. Kenen, Vol. II (North-Holland, Amsterdam).

Broner, Fernando, Norman Loayza, and Humberto Lopez, 1997, "Misalignment and Fundamentals: Equilibrium Exchange Rates in Seven Latin American Countries," unpublished, World Bank.

Canzoneri, Matt B., Robert E. Cumby, and Behzad Diba, 1999, "Relative Labor Productivity and the Real Exchange Rate in the Long Run: Evidence From a Panel of OECD Countries," Journal of International Economics, Vol. 47, pp. 245-66.

Chiang, Min-Hsien, and Chi-Hwa Kao, 2001, "Nonstationary Panel Time Series Using NPT 1.2 - User Guide," unpublished, Syracuse University.

Chinn, Menzie unpublished and Eswar Prasad, 2000, "Medium-Term Determinants of Current Accounts in Industrial and Developing Countries: An Empirical Exploration," IMF Working Paper 00/46. (Washington: International Monetary Fund).

Davidson, James A., 1998, "Structural Relations, Cointegration and Identification: Some Simple Results and Their Application," Journal of Econometrics, Vol. 87, 87-113.

De Gregorio, José, Alberto Giovannini and Holger Wolf, 1994, "International Evidence on Tradables and Nontradables Inflation," European Economic Review, Vol. 38, 1225-44.

Desruelle, Dominique and Alessandro Zanello, 1997, “A Primer on The Information Notice System," IMF Working Paper 97/71, (Washington: International Monetary Fund).

Driver, Rebecca, and Peter Westaway, 2001, "Concepts of Equilibrium Real Exchange Rates," unpublished, Bank of England. 
Faruqee, Hamid, 1995, "Long-Run Determinants of the Real Exchange Rate: A Stock-Flow Perspective," Vol. 42, pp. 80-107 Staff Papers, International Monetary Fund.

Gagnon, Joseph, 1996, "Net Foreign Assets and Equilibrium Exchange Rates: Panel Evidence," International Finance Discussion Paper No. 574 (Washington: Federal Reserve Board).

Hadri, Kaddour, 2000, "Testing for Stationarity in Heterogeneous Panel Data," Econometrics Journal, Vol. 3, pp. 148-61.

Hayashi, Fumio, 2000, Econometrics (Princeton: Princeton University Press).

International Monetary Fund, Balance of Payments Statistics, various issues.

— International Financial Statistics, various issues.

Kao, Chi-Hwa, and Min-Hsien Chiang, 1999, "On the Estimation and Inference of a Cointegrated Regression in Panel Data," unpublished, Center for Policy Research, Syracuse University.

Krugman, Paul, 1987, “Adjustment in the World Economy," NBER Working Paper No. 2424.

_, 1991, Has the Adjustment Process Worked?, (Washington: Institute for International Economics).

Lane, Philip R., 2001, “The New Open-Economy Macroeconomics: A Survey," Journal of International Economics, Vol. 54, pp. 235-266.

—, and Gian Maria Milesi-Ferretti, 2000, "The Transfer Problem Revisited: Net Foreign Assets and Real Exchange Rates," CEPR Discussion Paper No. 2511.

- 2001a, "The External Wealth of Nations: Estimates of Foreign Assets and Liabilities for Industrial and Developing Countries," Journal of International Economics, Vol. 55, pp. 263-294.

— , 2001b, "Long-Term Capital Movements," NBER Working Paper No. 8366 (forthcoming, NBER Macroeconomics Annual 2001).

MacDonald, Ronald, and Luca Ricci, 2001, "PPP and the Balassa-Samuelson Effect: The Role of the Distribution Sector," IMF Working Paper 01/38 (Washington: International Monetary Fund).

Mark, Nelson, and Donggyu Sul, 1999, “A Computationally Simple Vector Estimator for Panel Data," unpublished, Ohio State University. 
Mussa, Michael, 1984, "The Theory of Exchange Rate Determination," in Exchange Rates in Theory and Practice, ed. by J. Bilson and R. Marston, (Chicago: University of Chicago Press for NBER).

Obstfeld, Maurice, and Kenneth Rogoff, 1996, Foundations of International Macroeconomics, (Cambridge, Massachusetts: MIT Press).

— 2001a, "Perspectives on OECD Economic Integration: Implications for U.S. Current Account Adjustment," Global Economic Integration: Opportunities and Challenges, proceedings of a symposium sponsored by the Federal Reserve Bank of Kansas City, pp. 169-208.

— , 2001b, "The Six Major Puzzles in International Macroeconomics: Is There a Common Cause?" in NBER Macroeconomics Annual 2000, ed. by B. Bernanke and K. Rogoff, (Cambridge, Massachusetts: MIT Press).

OECD, 2000, Intersectoral Database Diskettes.

Pedroni, Peter, 1999, "Critical Values for Cointegration Tests in Heterogeneous Panels with Multiple Regressors," Oxford Bulletin of Economics and Statistics, Vol. 61, pp. $653-678$.

Rogers, John H., 2001, "Price Level Convergence, Relative Prices and Inflation in Europe," International Finance Discussion Paper No. 699. (Washington: Federal Reserve Board).

Stock, James, H., and Mark Watson, 1993, "A Simple Estimator of Cointegrating Vectors in Higher Order Integrated Systems," Econometrica, Vol. 61, pp. 783-820.

World Bank, World Development Indicators, various issues. 